\title{
A study on maternal near miss cases in tertiary care center, Chandrapur, Maharashtra, India
}

\author{
Priti Pralhad Ganvir, Sarika Thakare*
}

Department of Obstetrics and Gynecology, Government Medical College, Chandrapur, Maharashtra, India

Received: 16 July 2020

Accepted: 03 August 2020

*Correspondence:

Dr. Sarika Thakare,

E-mail: vivekpsy@gmail.com

Copyright: (c) the author(s), publisher and licensee Medip Academy. This is an open-access article distributed under the terms of the Creative Commons Attribution Non-Commercial License, which permits unrestricted non-commercial use, distribution, and reproduction in any medium, provided the original work is properly cited.

\begin{abstract}
Background: Obstetrics near miss is an important indicator that reflects the quality of obstetrics care in a health facility. It assesses and monitors the activities aimed for prevention of maternal mortality. The aim and objective of this study was to find out the incidence, the prevalence and the causes of maternal near miss cases due to severe obstetrics complications.

Methods: This is a retrospective study done in department of obstetrics and gynecology in GMC Chandrapur. The study was done during a period from $1^{\text {st }}$ January 2019 to $31^{\text {st }}$ December 2019.

Results: In this study the hospital maternal near miss incidence ratio was $13.11 \%$. In this study authors found the most common morbidity was $(36.06 \%)$ hypertensive disorders of pregnancy, $(28.68 \%)$ cases of major obstetric haemorrhage, $(7.37 \%)$ severe systemic infection or sepsis, $(2.45 \%)$ labour related disorders. In medical disorders very severe anaemia, $(13.11 \%)$ was most common cause of near miss. The most common cause of death was post-partum haemorrhage $(41.66 \%)$ and most of the patients referred from periphery in very critical condition.

Conclusions: Haemorrhage and hypertension disorders are the leading causes of MNM. Prompt diagnosis and adequate management of near miss cases can reduce mortality rates.
\end{abstract}

Keywords: Hypertensive disorders, Maternal mortality, Obstetric haemorrhage, Severe acute maternal morbidity

\section{INTRODUCTION}

Maternal mortality is a critical indicator to assess the quality of services provided by health care system. Women who experienced and survived a severe health condition during pregnancy, child birth or postpartum are considered as near miss or severe acute maternal morbidity cases. ${ }^{1}$

The major reasons and causes are the same for both MNM and MDR, so review of MNM cases is likely to yield valuable information regarding severe morbidity which could lead to death of mother, if not intervened properly and in time. According to WHO "a woman who survives life threatening conditions during pregnancy, abortion and childbirth or within 42 days of pregnancy termination, irrespective of receiving emergency medical/surgical interventions, is called maternal near miss." 2

By reviewing near miss cases, authors can learn about the processes and their deficiencies that are in place for the care of pregnant women. This would result in identifying the pattern of severe maternal morbidity and mortality, strengths and weakness in the referral system and the clinical intervention available and the ways in which improvements can be made. ${ }^{3}$

When MNMR is used in conjunction with MDR: 1) Aids in recognizing patterns and trends of maternal morbidity and mortality. 2) Helps in identifying contributory factors of maternal death so that actions can be taken at various levels. 3) Assists in evaluation of health care at facility and to monitor it. 4) Facilitates detection of lacunae in 
existing system. 5) Helps in setting up a database to capture all location and facility details to identify where an MNM case comes from; this assists in focusing interventions in particular location. 6) Beneficial in assessing and analysing requirement of health care facility in terms of interventional facilities, in terms of infrastructure, human resource and interventional facilities, besides comparing the existing health care and optimal health care of facility. 7) Identification of delays at various levels can be done, which lead to maternal morbidity and mortality. 8) Identify modifiable socialdemographic factors responsible for maternal morbidity and mortality. 9) It assists in international comparisons in imparting optimal health care. ${ }^{4}$

\section{METHODS}

This is a retrospective study done in department of obstetrics and gynecology in GMC Chandrapur. The study was done during a period from $1^{\text {st }}$ January 2019 to $30^{\text {th }}$ June 2019. GMC Chandrapur is a tertiary care hospital in Vidarbha region of Maharashtra state, India. This is a referral hospital. It provides 24 hours emergency obstetric services for both low and high-risk pregnant women. Data were collected from medical record.

For each case, booking, literacy, socio-economic status, gestational age, parity, referral or self-referred, mode of delivery, disease responsible for critical illness, nature of obstetric complications, presence of organ and/or systemic dysfunction, duration of hospital stay, source of referral, requirement of blood and blood products, surgical intervention to save the life of mother and other relevant information were collected from the medical records.

Different causes of maternal near miss were identified according to maternal near miss review operational guidelines - India December 2014. ${ }^{5}$

According to this study infrastructure and setting, authors have chosen some disease specific criteria and included pregnant and recently delivered women up to 6 weeks postpartum with one or more of the following entities: 1) Severe hypertension and hypertensive emergency are identified according to maternal near miss review operational guideline Dec 2014. 2) Haemorrhage leading to shock; emergency hysterectomy, coagulation defects and/or blood transfusion of $\geq 2$ litres in this study setting. 3) Uterine rupture defined as the occurrence of clinical symptoms such as pain, foetal distress, and acute loss of contractions, haemorrhage or intrauterine foetal death that led to laparotomy, at which the diagnosis was confirmed, or laparotomy for uterine rupture after vaginal birth. 4) Severe sepsis according to maternal near miss review operational guideline December 2014. 5) Very severe anaemia - authors have taken very severe anaemia cases of $\mathrm{Hb}<6 \mathrm{gm} / \mathrm{dl}$ in my study who require $\geq 3$ units of blood or PRC's and multiple doses of injectable iron.

\section{RESULTS}

This is a retrospective study done in department of obstetrics and gynecology in GMC Chandrapur. The study was done during a period from $1^{\text {st }}$ January 2019 to $30^{\text {th }}$ June 2019. During this period 11,448 ANC cases were admitted in hospital, out of which 9527 patients were delivered, 2204 patients required lower segment caesarean section (LSCS), giving a LSCS rate of $23.13 \%$. 9300 live births were there and 122 cases were diagnosed as near miss.

Table 1: Socio-demographic variables, parity and gestational age of patients $(n=122)$.

\begin{tabular}{|c|c|c|}
\hline Variables & Number & $\%$ \\
\hline \multicolumn{3}{|l|}{ Age of patients (years) } \\
\hline $15-20$ & 17 & 13.93 \\
\hline $21-25$ & 62 & 50.81 \\
\hline $26-35$ & 33 & 27.04 \\
\hline$>35$ & 10 & 8.19 \\
\hline \multicolumn{3}{|l|}{ Parity } \\
\hline 0 & 70 & 57.37 \\
\hline 1 & 36 & 29.50 \\
\hline 2 & 11 & 9.01 \\
\hline$>2$ & 05 & 4.09 \\
\hline \multicolumn{3}{|l|}{ Gestational age } \\
\hline$<12$ weeks & 05 & 4.09 \\
\hline 13-28 weeks & 07 & 5.73 \\
\hline 29-36 weeks & 32 & 26.22 \\
\hline $37-40$ weeks & 68 & 55.73 \\
\hline$>40$ weeks & 06 & 4.91 \\
\hline Post-partum & 04 & 3.27 \\
\hline \multicolumn{3}{|l|}{ Booking status } \\
\hline Booked & 51 & 41.80 \\
\hline Unbooked & 71 & 58.19 \\
\hline \multicolumn{3}{|l|}{ Literacy } \\
\hline Illiterate & 63 & 51.63 \\
\hline Literate & 59 & 48.36 \\
\hline \multicolumn{3}{|l|}{ Socio-economic status } \\
\hline Low & 81 & 66.39 \\
\hline Middle & 37 & 30.32 \\
\hline High & 04 & 3.27 \\
\hline \multicolumn{3}{|l|}{ Referral status } \\
\hline Self & 33 & 27.04 \\
\hline $\begin{array}{l}\text { Referred from other health } \\
\text { centres }\end{array}$ & 89 & 72.95 \\
\hline
\end{tabular}

Authors have calculated intra hospital maternal near miss incidence ratio (number of maternal near miss cases per 1000 live birth) (MNM IR = MNM/LB). In my study the hospital maternal near miss incidence ratio was $13.11 \%$ per 1000 live birth. Table 1 shows the demographic details of these 122 women. In this study most women $(50.81 \%)$ were of age between $21-25$ years, $57.37 \%$ were primipara, $58.19 \%$ patients were unbooked and were admitted in emergency (Table 1). 
Table 2: Causes of near miss cases $(n=122)$.

\begin{tabular}{|c|c|c|c|}
\hline Diagnosis & & $\mathbf{N}$ & $\%$ \\
\hline $\begin{array}{l}\text { Hypertensive } \\
\text { disorders in } \\
\text { pregnancy }\end{array}$ & $\begin{array}{l}\text { Chronic hypertension } \\
\text { Severe PIH } \\
\text { Severe pre-eclampsia with signs of organ dysfunction } \\
\text { Eclampsia with organ dysfunction } \\
\text { HELLP syndrome }\end{array}$ & 44 & 36.06 \\
\hline $\begin{array}{l}\text { Severe } \\
\text { Haemorrhage }\end{array}$ & $\begin{array}{l}\text { Haemorrhage due to RPOC's and inevitable abortion } \\
\text { Ruptured ectopic pregnancy with severe anaemia and shock } \\
\text { Placenta praevia and placental abruption intraoperative haemorrhage } \\
\text { Ruptured uterus } \\
\text { Severe post-partum haemorrhage } \\
\text { Haemorrhage due to retained placenta } \\
\text { Genital tract injuries and large hematoma }\end{array}$ & 35 & 28.68 \\
\hline $\begin{array}{l}\text { Severe } \\
\text { systemic } \\
\text { infection or } \\
\text { sepsis }\end{array}$ & $\begin{array}{l}\text { Septic abortion } \\
\text { Chorio amnionitis } \\
\text { Puerperal sepsis } \\
\text { Postsurgical procedure severe infection (e.g. caesarean section, laparotomy, } \\
\text { evacuation, manual removal placenta and others.) }\end{array}$ & 9 & 7.37 \\
\hline $\begin{array}{l}\text { Labour related } \\
\text { disorders }\end{array}$ & Prolonged and obstructed labour with complications, rupture uterus and others & 3 & 2.45 \\
\hline $\begin{array}{l}\text { Postpartum } \\
\text { collapse }\end{array}$ & Amniotic fluid embolism, inversion of uterus with complications & 2 & 1.63 \\
\hline Medical disorde & & & \\
\hline $\begin{array}{l}\text { Very severe } \\
\text { anaemia }\end{array}$ & $>3$ blood transfusion/PRC's and multiple doses of iron sucrose & 16 & 13.11 \\
\hline $\begin{array}{l}\text { Cardiovascular } \\
\text { dysfunction }\end{array}$ & Valvular disease, arrhythmia, cardio myopathy, infarction & 2 & 1.63 \\
\hline $\begin{array}{l}\text { Respiratory } \\
\text { dysfunction }\end{array}$ & $\begin{array}{l}\text { ARDS } \\
\text { Pulmonary edema } \\
\text { Post-operative pneumonia and others } \\
\text { Severe tuberculosis with respiratory failure }\end{array}$ & 5 & 4.09 \\
\hline $\begin{array}{l}\text { Renal } \\
\text { dysfunction }\end{array}$ & Oliguria needed multiple doses of diuretics/dialysis acute renal failure & 2 & 1.63 \\
\hline $\begin{array}{l}\text { Coagulation } \\
\text { dysfunction }\end{array}$ & DIC & 3 & 2.45 \\
\hline $\begin{array}{l}\text { Neurological } \\
\text { dysfunction }\end{array}$ & Intracranial haemorrhage, non-eclamptic seizures & 1 & 0.81 \\
\hline Total & & 122 & $100 \%$ \\
\hline
\end{tabular}

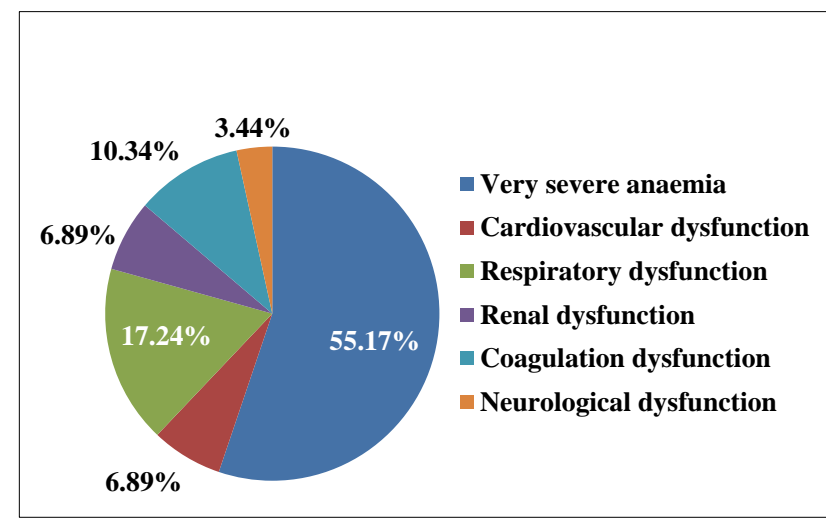

Figure 1: Medical disorders, as a cause of near miss cases.

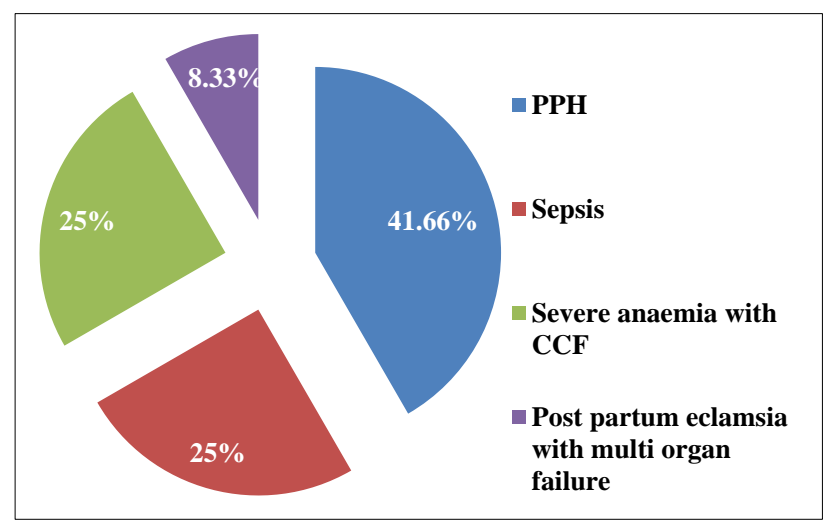

Figure 2: Maternal mortality and associated causes. 
Literacy level was low and majority (66.39\%) were belonging to low socio-economic group. Majority of the patients $(55.73 \%)$ were in third trimester. $72.95 \%$ patients were referred from periphery, as ours is a tertiary care centre (Table 1).

In this study authors found the most common morbidity was $(36.06 \%)$ hypertensive disorder of pregnancy (Table 2).

In this study very severe anaemia (13.11\%) was the commonest medical disorder found in near miss cases, these women presented with generalised oedema, weakness, dyspnoea and unable to perform routine work (Figure 1).

During this period there were 12 maternal deaths. The most common cause of death was post-partum haemorrhage (41.66\%) (Figure 2).

\section{DISCUSSION}

In this study $50.81 \%$ of women were in age group of 21 25 years. $58.19 \%$ were unbooked. $57.37 \%$ were primipara, $55.73 \%$ were full term patients. $66.39 \%$ were belonging to low socio-economic status.

My study is comparable with one other study, in which $55.34 \%$ of women with near miss cases in their hospital were in the age group of $21-25$ years, $40.88 \%$ were primipara, $50.94 \%$ were term patients and $64.15 \%$ were from low income group. ${ }^{6}$

In one another study most women $(67.85 \%)$ were in the age group less than 25 years, $64.28 \%$ were unbooked and were admitted in emergency, literacy rate was low and majority were from low socio-economic group. ${ }^{7}$

The MNM IR is $13.11 \%$ in this study which is comparable to study of Jain et al, with maternal near miss incidence ratio was $14.34 / 1000$ live birth. ${ }^{8}$

The incidence of SAMM was 15 and 17.8 per 1000 live birth in study of Moraes et al, and PS et al, respectively. ${ }^{9,10}$ The incidence of severe maternal morbidity was 3.3/1000 deliveries in study by Chhabra et al, and Waterstone et al reported a severe obstetric morbidity rate of 12.0/1000 live births, which was lower than my study. ${ }^{11,12}$ In this study authors found the most common morbidity was $(30.18 \%)$ hypertensive disorder of pregnancy, second was $(27.67 \%$ severe haemorrhage.

In this study, very severe anaemia $(13.11 \%)$ was the most common medical disorder found in near miss cases. The other studies from our country have also reported severe anaemia as one of the important causes and contributory factor to severe maternal morbidity and mortality, 19 even after implementation of different programs for controlling iron deficiency anaemia, the magnitude of this problem is still high.
During this period, 12 patients died, out of which 5 $(41.66 \%)$ patients were died due to post-partum haemorrhage. It is comparable with the study conducted by Mehta et al, showed major cause of death in this study was haemorrhage. ${ }^{20}$

Globally, there has been a paradigm shift in the maternal care strategy since 1990's. In India also there has been a policy change with promotion of institutional births, births by skilled birth attendants and provision of emergency obstetric care. ${ }^{21}$

Reduction of maternal and neonatal morbidity and mortality is one of the key objectives of the National health mission (NHM), so that India achieves the SDG target of MMR of less than 70 per lakh live births.

The Janani Suraksha Yojana (JSY) a cash incentive scheme has been initiated to promote institutional deliveries in India. Ministry of Health and Family Welfare has recently launched the program 'LaQshaya' aimed at further improving quality of care in pregnant women in labour room, maternity operation theatre and obstetric intensive care units (ICU) and high dependency units (HDU). ${ }^{22}$

Efforts geared towards improvements in the management of near miss morbidities would definitely go a long way in reducing the present maternal morbidity and mortality ratio.

\section{CONCLUSION}

According to this study, hypertension and haemorrhagic disorders are the leading causes of maternal near miss. Efforts must be made to improve maternal care for hypertension and haemorrhagic disorders. Other lifethreatening conditions like severe anaemia, infection and other medical disorders in pregnancy should also be taken care of. It is well known that complications during pregnancy and child birth can occur at any point of time, and it is important to ensure that readiness in terms of infrastructure, equipment's, etc, for timely management of complications should be made available at all the basic and emergency obstetric care health facilities. A regular audit of near miss cases and reporting of these cases to higher authorities should be done so that appropriate action can be taken at all health care levels. Proper data management must be done for quick and effective treatment. Prompt diagnosis, appropriate action and timely interventions will reduce maternal morbidity and mortality.

\section{ACKNOWLEDGMENTS}

Authors would like to thank Dr. Yeole V, an obstetrician and gynecologist for helping her in this study.

Funding: No funding sources

Conflict of interest: None declared

Ethical approval: Not required 


\section{REFERENCES}

1. Kaur R, Roy D, Aggarwal P, Nautiyal R, Chaturvedi J, Kakkar R. Application of WHO near miss tool indicates good quality of maternal care in rural healthcare setting in Uttarakhand, Northern India. J Clin Diag Res. 2016;10(1):LC10-3.

2. Pattinson RC, Say L, Souza JP, Broek NV, Rooney C. WHO working group on maternal mortality and morbidity classifications. WHO Maternal death and near miss classifications. Bull World Health Organ. 2009;87(10):734.

3. Tallapureddy S, Velagaleti R, Palutla H, Satti CV. Near miss, obstetric events and maternal mortality in a tertiary care hospital. Indian $\mathrm{J}$ Public Health. 2017;61(4):350.

4. Elnashar A. Behna University Hospital, Egypt, maternal near miss - slide share, 2018. Available at: http://www.slideshare.net.elsashar. Accessed on $12^{\text {th }}$ October 2019.

5. Mishra CK. Maternal near miss review operational guidelines. 2014, Annexure 2:35-40; Available at: http://www.nrhmorissa.gov.in/writereaddata/Upload/ Documents/Maternal_Near_Miss_Operational_Guid elines.pdf. Accessed on $14^{\text {th }}$ October 2019.

6. Sharma S, Aherwar R, Jawadhe S. Retrospective study of maternal near miss cases in a tertiary care institute. Int J Reprod Contracept Obstets Gynaecol. 2016;5(4):1114-8.

7. Kaur N, Aryal S. Pattern of severe acute maternal morbidity in a tertiary care institute. J Lumbini Med Coll. 2015;3(2):45-9.

8. Jain U. A study on maternal near miss cases in Government Medical College, Shivpuri, India. Int J Reprod Contracept Obstet Gynaecol. 2019;8(8):3047-55.

9. Moraes AP, Baretto SM, Passos VM, Golino PS, Costa JA, Vasconcelos MX. Incidence and main causes of severe maternal morbidity in Sao Lusis, Maranhao, Brazil: a longitudinal study. Sao Paulo Med J. 2011;129:146-52.

10. Sangeeta G, Leena W, Taru G, Sushma K, Nupur G, Amrita P, et al. Evaluation of severe maternal outcomes to assess quality of maternal health care at a tertiary centre. J Obstet Gynaecol India. 2015;65:23-7.

11. Chhabra P, Guleria K, Saini N, Anjur KT. Pattern of severe maternal morbidity in a tertiary hospital of Delhi, India: a pilot study. Trop Doctor. 2008:38(4):201-4.

12. Waterstone M, Bewley S, Wolfe C. Incidence and predictors of severe obstetric morbidity: case-control study. MBJ. 2001;322(7294):1089-4.
13. Upadhyaya I, Chaudhary P. Severe acute maternal morbidity and intensive care in Paropkar maternity and women's hospital. NJOG. 2013:8(2):38-41.

14. Moraes AP, Baretto SM, Passos VM, Golino PS, Costa JA, Vasconcelos MX. Incidence and main causes of severe maternal morbidity in Sao Lusis, Maranhao, Brazil: a longitudinal study. Sao Paulo Med J. 2011:129:146-52.

15. Huseyin C, Cihan K, Ramzan A, Ziya YY, Murat E, Levent Y. Near miss obstetric cases: 4 years experience of tertiary centre. Gynecol Obstet Reprod Med. 2013;19(1):19-22.

16. Sauza JP, Cecatti JG, Parpinelli MA, Seruyya SJ, Amaral E. Appropriate criteria for identification of near miss maternal morbidity in tertiary care facilities: a cross sectional study. BMC Preg Child Birth. 2007;7(1):20.

17. Taly A, Gupat S, Jain N. Maternal intensive care and near miss mortality in obstetric. J Obstet Gynecol India. 2004;54(5):478-82.

18. Roost M, Altamirano VC, Liljestrand J, Essen B. Priorities in emergency obstetric care in Bolivia maternal mortality and maternal near miss in metropolitan LA Paz. BJOG. 2009;116(9):1210-7.

19. Daru J, Zamora J, Fernández-Félix BM, Vogel J, Oladapo OT, Morisaki N, Tunçalp Ö, et al. Risk of maternal mortality in women with severe anaemia during pregnancy and postpartum: a multilevel analysis. The Lancet Global Health. 2018;6(5):e54854.

20. Mehta M, BAVarva N. Facility base maternal death review at tertiary care hospital: a small effort of Explore Hidden facts. Appl med Res. 2016;I(4):1269.

21. National program Implementation plan RCH phase II - program document. Available at: http://mohfw.nic.in/NRHM/RCH/guidelines/PIP/Rev III.pdf. Accessed on 21 ${ }^{\text {st }}$ February 2012.

22. LaQshya. Labour room quality improvement initiative in: National health mission; ministry of health and family welfare government of India. 2017:3:12-4

Cite this article as: Ganvir PP, Thakare S. A study on maternal near miss cases in tertiary care center, Chandrapur, Maharashtra, India. Int J Reprod Contracept Obstet Gynecol 2020;9:3602-6. 